Tropical Journal of Pharmaceutical Research January 2018; 17 (1): 91-96

ISSN: $1596-5996$ (print); 1596-9827 (electronic)

(c) Pharmacotherapy Group, Faculty of Pharmacy, University of Benin, Benin City, 300001 Nigeria.

Available online at http://www.tjpr.org

Original Research Article

http://dx.doi.org/10.4314/tjpr.v17i1.14

\title{
Effect of dietary soy isoflavones on bone loss in ovariectomized rats
}

\author{
Haidong Liang ${ }^{1,2}$, Fang $\mathrm{Yu}^{3}$, Bo Yuan ${ }^{2}$, Zheng Nan Zhao ${ }^{2}$, Chang Gui Tong ${ }^{2}$, Xue \\ Hui Liư ${ }^{2}$, ShuFang $\mathrm{Wu}^{1 *}$ \\ ${ }^{1}$ Center for Translational Medicine, The First Affiliated Hospital of Xi'an Jiaotong University School of Medicine, 277 West Yanta \\ Road, Xi'an, Shaanxi 710061, ${ }^{2}$ Hands and Feet Microsurgery, The Second Hospital of Dalian Medical University, Dalian \\ 116023, People's Republic of China, ${ }^{3}$ The Second Hospital of Dalian Medical University, Dalian 116023, People's Republic of \\ China
}

*For correspondence: Email: sfangwu@aliyun.com; Tel: +86-029-85324555

Sent for review: 7 July 2017

Revised accepted: 14 October 2017

\begin{abstract}
Purpose: To determine the effect of dietary soy isoflavone supplementation on bone loss in ovariectomized (OVX) rats.

Methods: Forty-eight rats were assigned randomly to groups of OVX rats receiving soy isoflavones $(20$, 30 , or $40 \mathrm{mg} / \mathrm{kg}$ of body weight daily), untreated OVX rats, or untreated intact rats. After 8 weeks, bone mineral density (BMD), mineral (Ca, $P, M n, M g$, and $\mathrm{Zn}$ ) concentrations, and the expression of osteoblast-related genes were measured in femur tissue samples.

Results: Eight weeks after OVX, there was a significant decrease in body weight, serum levels of osteocalcin, alkaline phosphatase, and oestradiol, BMD and mineral elements, as well as the expressions of Ctnnb1, Runx2, and Sp7 (all $p<0.05$ ). These decreases were accompanied by reduced maximum load capacity of lumbar vertebrae. Daily supplementation with soy isoflavones dosedependently ameliorated these effects (all $p<0.05)$. Western blotting revealed that these effects were likely due to the reversal of the OVX-induced decrease in Notch1 proteins in bone and muscle.

Conclusion: Soy isoflavone treatment represents a potential therapy for preventing postmenopausal bone loss by stimulating the Notch signalling.
\end{abstract}

Keywords: Mineral elements, Alkaline phosphatase, Isoflavones, Bone loss, Notch pathway

\footnotetext{
This is an Open Access article that uses a funding model which does not charge readers or their institutions for access and distributed under the terms of the Creative Commons Attribution License (http://creativecommons.org/licenses/by/4.0) and the Budapest Open Access Initiative (http://www.budapestopenaccessinitiative.org/read), which permit unrestricted use, distribution, and reproduction in any medium, provided the original work is properly credited.
}

Tropical Journal of Pharmaceutical Research is indexed by Science Citation Index (SciSearch), Scopus, International Pharmaceutical Abstract, Chemical Abstracts, Embase, Index Copernicus, EBSCO, African Index Medicus, JournalSeek, Journal Citation Reports/Science Edition, Directory of Open Access Journals (DOAJ), African Journal Online, Bioline International, Open-J-Gate and Pharmacy Abstracts

\section{INTRODUCTION}

Postmenopausal osteoporosis is a common condition in which reduced levels of oestrogen alter the mineral composition of bone, leading to a loss of mineralized bone tissue and structural failure (fracture) [1-4]. To delay the loss of bone minerals and thereby prevent bone fractures, treatment strategies have included oestrogen replacement or the administration of selective oestrogen receptor modulators, such as raloxifene, bisphosphonates, and calcitonin. However, these therapies increase the risk of hypercalcemia, hypercalciuria, hot flushes, and endometrial cancer [5-7]. 
Interestingly, isoflavones are chemically similar to oestradiol (E2) and bind to both alpha- and beta-oestrogen receptors, resulting in either the stimulation of globulin production or inhibition of aromatase activity [8]. There is evidence that isoflavones reduce the risk of endometrial cancer by interfering with oestrogen hormone production and signalling. As a subclass of plant-based polyphenols, isoflavones are present in legumes and are in particularly high concentrations in soy products [8]. Thus, the dietary intake of these compounds may influence the deposition of minerals in bone tissue in individuals with low levels of oestrogen.

In this study, we examined whether the intake of dietary soy isoflavones impacts bone mineral density (BMD) to prevent bone loss in animals with oestrogen deficiencies. For this, we analysed the mineral composition and transcription of osteoblast-related genes in vertebral and femur tissues from ovariectomized (OVX) rats, which have been shown to demonstrate progressive losses of bone matrices [9].

\section{EXPERIMENTAL}

\section{Isolation and HPLC analysis of soy isoflavones}

Soy isoflavones were isolated from defatted soy flour. Briefly, the flour was mixed with $100 \mathrm{~mL}$ of a methanol-water solution ( $4: 1$ ratio) in a $150-\mathrm{mL}$ glass tube that was rotated for $3 \mathrm{~h}$ at $30 \mathrm{rpm}$ at $35 \pm 0.1 \mathrm{C}$. The solution was then placed under vacuum in a rotary evaporator to concentrate the extracts, which were then filtered and stored at $80^{\circ} \mathrm{C}$.

The extracts were analysed by high-performance liquid chromatography (HPLC) using an HPLC system (Waters 2459; Waters Corp., Milford, MA, USA) with a $5-\mu \mathrm{m}(4.6 \times 250 \mathrm{~mm})$ Waters Sunfire $\mathrm{C}_{18}$ column maintained at 25C. HPLC was conducted with $20-\mu \mathrm{L}$ injections, a $0.9-\mathrm{ml} / \mathrm{min}$ flow rate (Waters 515 HPLC pump), a 210-nm detection wavelength, and a run time of $30 \mathrm{~min}$. For the mobile phase, we used an isopropanol and acetonitrile mixture (1:24 [vol/vol]). Solutions of glycitin, daidzin, genistin daidzein, genistein, and glycitein were used as standards.

\section{Animals}

Forty-eight female wistar rats (3 months old; 230$250 \mathrm{~g}$ ) were assigned randomly to groups of OVX rats receiving daily soy isoflavones $(20,30$, or $40 \mathrm{mg} / \mathrm{kg}$ of body weight), untreated OVX rats, or untreated intact rats. Rats were anaesthetized with pentobarbital for surgeries to remove both ovaries; in the intact rats, the ovaries were exposed but not removed. The animals receiving treatments were given oral (intragastric administration) doses of isoflavones once daily for 8 weeks. The procedures in this study were approved by the ethics committee of Dalian Medical University.

All experimental protocols were approved by the Ethics Committee of Dalian Medical University (approval no. 170616) according to the guidelines put forth by the National Institutes of Health Guide for the Care and Use of Laboratory Animals [10].

\section{Assessment of BMD and composition}

After 8 weeks, animals were anesthetized with pentobarbital for the measurement of the BMD of the lumbar vertebrae (L2 to L4) and the left femurs by dual-energy X-ray absorptiometry (Lunar, USA) as described previously [11]. The animals were sacrificed by $\mathrm{CO}_{2}$ asphyxiation, and the length and width of each femur (midshaft) were measured with digital callipers. The concentrations of $\mathrm{Ca}, \mathrm{P}, \mathrm{Mn}, \mathrm{Mg}$, and $\mathrm{Zn}$ in bone tissue were determined by atomic absorption spectrometry (Type 180-70; Hitachi Co., Tokyo, Japan).

\section{Biochemical analyses}

Blood samples were collected prior to asphyxiation, and the resulting serum obtained after centrifugation (20 min at 3,000 rpm) was stored at $-2{ }^{\circ} \mathrm{C}$. Alkaline phosphatase (ALP) activities in serum were assayed with standard commercial colorimetric kits (Zhongsheng BeiKong Bio-technology and Science, China) on an automatic biochemical analyser (Cobas Integra 400 Plus; Roche Diagnostics, Switzerland). A A double-antibody radioimmunoassay kit was used to determine osteocalcin (BGP) and E2 levels on a gammaray counter [12].

\section{Quantitative real-time PCR}

Trizol reagent (Invitrogen) was used to extract total RNA from bone tissues for quantitative realtime PCR with SYBR green on a Light Cycler 480 II (Roche Diagnostics). The expressions of osteoblast-specific osterix (Sp7), -catenin (Ctnnb1), runt-related transcription factor 2 (Runx2), and -actin (Actb; reference gene) were determined by using the primers listed in Table 1. Each reaction was performed in triplicate and was repeated three times. Relative cycle 
threshold $\left(C_{T}\right)$ values were used to quantify gene expression according to the $2^{-C T}$ method.

Table 1: Primer sequences

\begin{tabular}{|c|c|c|}
\hline Gene & $\begin{array}{l}\text { Primer } \\
\text { direction }\end{array}$ & Sequence (53) \\
\hline \multirow[t]{2}{*}{ Ctnnb1 } & Forward & $\begin{array}{l}\text { ACTCTAGTGCAGCT } \\
\text { TCTGGGTTCTG }\end{array}$ \\
\hline & Reverse & $\begin{array}{l}\text { CTCGGTAATGTCCT } \\
\text { CCCTGTCA }\end{array}$ \\
\hline \multirow[t]{2}{*}{ Runx2 } & Forward & $\begin{array}{l}\text { AGCGGACGAGGCA } \\
\text { ACAGTTT }\end{array}$ \\
\hline & Reverse & $\begin{array}{l}\text { CCTAAATCACTGAG } \\
\text { GCGGTCAG }\end{array}$ \\
\hline \multirow[t]{2}{*}{ Sp7 } & Forward & $\begin{array}{l}\text { CCACCCATTGCCAG } \\
\text { TAATCT }\end{array}$ \\
\hline & Reverse & $\begin{array}{l}\text { TTCTTTGTGCCTCCT } \\
\text { TTTCC }\end{array}$ \\
\hline \multirow[t]{2}{*}{ Actb } & Forward & $\begin{array}{l}\text { CACTTTCTACAATGA } \\
\text { GCTGCG }\end{array}$ \\
\hline & Reverse & $\begin{array}{l}\text { CTGGATGGCTACGT } \\
\text { ACATGG }\end{array}$ \\
\hline
\end{tabular}

\section{Western blot}

Total proteins from $50-\mathrm{mg}$ samples of bone and muscle tissue were extracted with RIPA lysis buffer. A BCA protein assay (Pulilai, China) was used to measure protein concentrations. Protein samples $(80 \mu \mathrm{g})$ were separated by SDS-PAGE on $10 \%$ gels and transferred to polyvinylidene difluoride membranes. The membranes were first incubated for $3 \mathrm{~h}$ in 5\% non-fat-milk blocking solution at room temperature, followed by an overnight incubation at 4C with anti-Notch1 or anti-Gapdh antibodies $(1: 1,000)$. After incubating with appropriate secondary antibodies, the proteins were visualized via enhanced chemiluminescence. The densities of the bands for each protein were measured using ImageJ (National Institutes of Health, USA), and Notch1 expression was normalized to that of Gapdh.

\section{Statistical analysis}

Data are presented as mean \pm SD and were analysed by one-way analysis of variance using SPSS software (version 12.0). $P<0.05$ was considered statistically significant.

\section{RESULTS}

The isoflavone composition of the extracts was $2.13479 \mathrm{ng} / \mu \mathrm{L}$ genistin, $13.86087 \mathrm{ng} / \mu \mathrm{L}$ glycitin, $4.15441 \mathrm{ng} / \mu \mathrm{L}$ daidzin, $32.23469 \mathrm{ng} / \mu \mathrm{L}$ genistein, and $34.26970 \mathrm{ng} / \mu \mathrm{L}$ daidzein, (Figure 1).

Ovariectomy significantly reduced the mean BMD values after 8 weeks $(p<0.05)$ (Figure 3$)$. However, daily soy isoflavone supplementation dose-dependently increased BMD values in OVX rats.

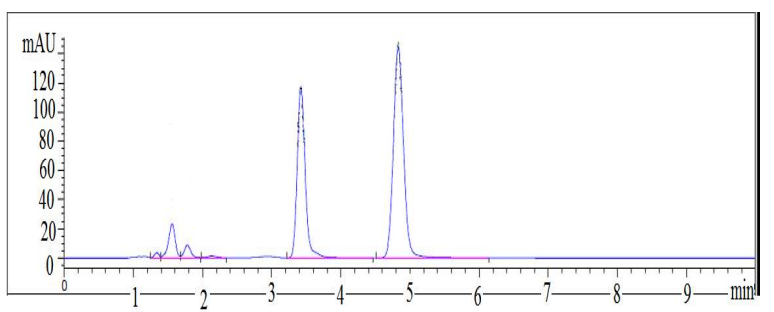

Figure 1: HPLC chromatogram of soy isoflavones

The average initial and final body weights from all groups are presented in Figure 2. Over the 8week study, the body weights of all animals increased; however, the OVX rats were significantly heavier than those of the intact group $(p<0.05)$. Isoflavone supplementation attenuated the weight increase over the 8-week study in a dose-dependent manner.

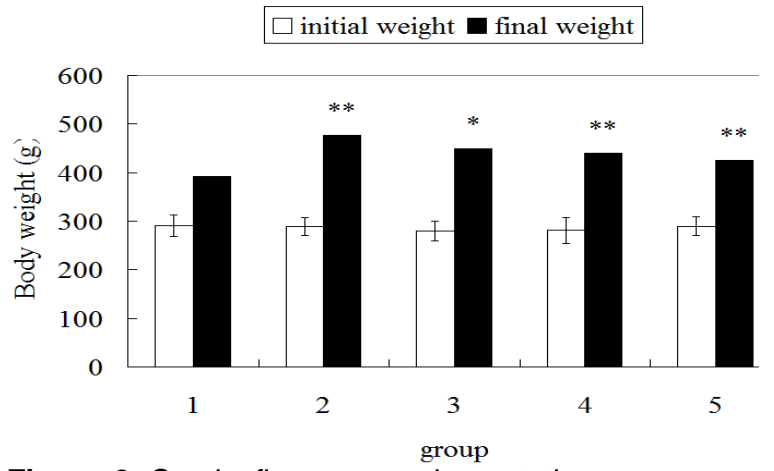

Figure 2: Soy isoflavone supplementation suppresses weight gain in OVX rats. 1, intact rats; 2, untreated OVX rats; $3-5$, OVX rats treated with 20,30 , or 40 $\mathrm{mg} / \mathrm{kg}$ isoflavones, respectively; ${ }^{*} p<0.05,{ }^{* *} p<0.01$

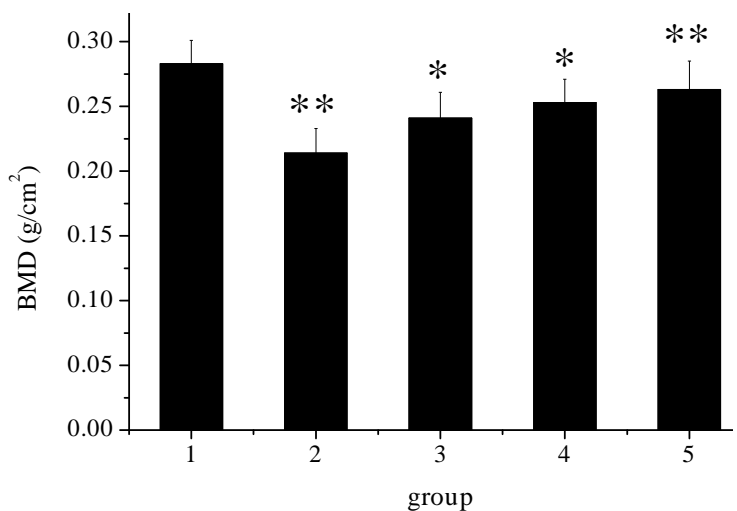

Figure 3: Soy isoflavone supplementation suppresses the reduction of BMD $\left(\mathrm{g} / \mathrm{cm}^{2}\right)$ in OVX rats. 1, intact rats; 2 , untreated OVX rats; $3-5$, OVX rats treated with 20,30 , or $40 \mathrm{mg} / \mathrm{kg}$ isoflavones, respectively; * $p<$ $0.05,{ }^{* *} p<0.01$

Serum levels of BGP, ALP, and E2 measured after 8 weeks were significantly $(p<0.01)$ higher in intact rats than in OVX rats (Table 2). Furthermore, the administration of soy 
isoflavones dose-dependently increased serum BGP, ALP, and E2 levels in OVX rats.

Table 2: Serum BGP, ALP and E2 levels

\begin{tabular}{lccc}
\hline Group & BGP (ng/L) & $\begin{array}{c}\text { ALP } \\
(\mathbf{U} / \mathbf{L})\end{array}$ & $\begin{array}{c}\text { E2 } \\
(\mathbf{p g} / \mathbf{m L})\end{array}$ \\
\hline Intact & $2,273.87 \pm$ & $111.32 \pm$ & $8.59 \pm$ \\
& 163.26 & 8.52 & 0.57 \\
OVX & $1,794.01 \pm$ & $77.27 \pm$ & $3.72 \pm$ \\
untreated & 106.28 & 2.73 & 0.14 \\
OVX + 20 & $1843.77 \pm$ & $88.46 \pm$ & $5.51 \pm$ \\
$\mathrm{mg} / \mathrm{kg}$ & 99.42 & 3.66 & 0.26 \\
OVX + 30 & $1,972.48 \pm$ & $93.14 \pm$ & $6.93 \pm$ \\
$\mathrm{mg} / \mathrm{kg}$ & 83.59 & 5.03 & 0.51 \\
$\mathrm{OVX}+40$ & $2,193.15 \pm$ & $106.91 \pm$ & $7.27 \pm$ \\
$\mathrm{mg} / \mathrm{kg}$ & 131.53 & 8.36 & 0.39 \\
\hline
\end{tabular}

Daily soy isoflavone supplementation also affected the concentrations of $\mathrm{Ca}, \mathrm{P}, \mathrm{Mg}, \mathrm{Mn}$, and $\mathrm{Zn}$ in bone tissues as shown in Table 3 . The levels of all elements were significantly higher in intact rats than in untreated OVX rats. However, the administration of soy isoflavones to OVX rats significantly and dose-dependently increased $\mathrm{Ca}$, $\mathrm{P}, \mathrm{Mg}, \mathrm{Mn}$, and $\mathrm{Zn}$ concentrations compared to those in the untreated OVX model group.

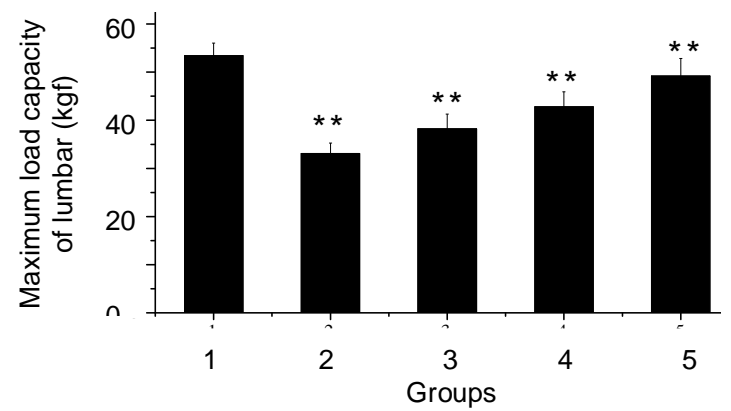

Figure 4: Soy isoflavone supplementation increases the maximum load capacity of lumbar vertebrae. 1, intact rats; 2, untreated OVX rats; $3-5$, OVX rats treated with 20,30 , or $40 \mathrm{mg} / \mathrm{kg}$ isoflavones, respectively; ${ }^{* *} p<0.05$

The maximum lumbar load capacity was significantly reduced after 8 weeks in OVX rats (Figure 4). However, animals receiving isoflavone supplementation demonstrated Table 3: Concentration of minerals in bone significantly higher $(p<0.05)$ load capacities than those of the untreated OVX rats, an effect that also appeared to be dose dependent.

We also measured gene expression levels in bone tissue samples. We found that relative to the levels in intact animals, the transcription of genes encoding $\beta$-catenin, runt-related transcription factor 2, and osterix (Ctnnb1, Runx2, and Sp7, respectively) were reduced in the femurs of OVX rats (Table 4). However, the levels of all three transcripts were significantly higher $(p<0.05)$ in the OVX rats that were treated with soy isoflavones, with the largest difference observed with the high-dose soy isoflavone treatment.

Table 4: Gene expression in femur tissue

\begin{tabular}{lccc}
\hline Group & Ctnnb1 & Runx2 & Sp7 \\
\hline Intact & $1.00 \pm 0.04$ & $1.00 \pm$ & $1.00 \pm$ \\
& & 0.02 & 0.03 \\
OVX & $0.38 \pm 0.06$ & $0.29 \pm$ & $0.31 \pm$ \\
untreated & & 0.04 & 0.03 \\
OVX +20 & $0.49 \pm 0.09$ & $0.41 \pm$ & $0.52 \pm$ \\
$\mathrm{mg} / \mathrm{kg}$ & & 0.03 & 0.09 \\
OVX +30 & $0.62 \pm 0.12$ & $0.55 \pm$ & $0.79 \pm$ \\
$\mathrm{mg} / \mathrm{kg}$ & & 0.09 & 0.08 \\
OVX +40 & $0.86 \pm 0.14$ & $0.95 \pm$ & $1.14 \pm$ \\
$\mathrm{mg} / \mathrm{kg}$ & & 0.11 & 0.11 \\
\hline
\end{tabular}

We also examined the protein expression of Notch1 in samples of femur and muscle tissue. There was a dramatic loss of Notch1 protein in the femurs and muscles of OVX rats (Figure $5 \mathrm{~A}$ and $B$, respectively). However, daily treatment with soy isoflavones increased the expression of Notch1 protein significantly $(p<0.05)$ in OVX rats. The effect was most pronounced in animals treated with a high-dose of soy isoflavones.

\section{DISCUSSION}

The loss of bone and bone strength in individuals with osteoporosis contributes to fractures as a result of longer durations of resorption phases during bone remodelling [13]. During menopause, this enhancement of bone resorpt-

\begin{tabular}{lccccc}
\hline Group & $\mathbf{C a}(\boldsymbol{\mu g} / \mathbf{g})$ & $\mathbf{P}(\boldsymbol{\mu g} / \mathbf{g})$ & $\mathbf{M g}(\boldsymbol{\mu g} / \mathbf{g})$ & $\mathbf{M n}(\boldsymbol{\mu g} / \mathbf{g})$ & $\mathbf{Z n}(\boldsymbol{\mu g} / \mathbf{g})$ \\
\hline Intact & $394,814.37 \pm$ & $241,705.36 \pm$ & $9,128.39 \pm$ & $0.93 \pm 0.03$ & $392.15 \pm$ \\
& 679.54 & 402.51 & 82.05 & & 16.21 \\
OVX untreated & $371,306.47 \pm$ & $207,351.44 \pm$ & $7,603.42 \pm$ & $0.81 \pm 0.04$ & $362.71 \pm$ \\
& 628.31 & 573.14 & 67.39 & & 18.48 \\
OVX + $20 \mathrm{mg} / \mathrm{kg}$ & $377,392.29 \pm$ & $214,072.03 \pm$ & $7,836.35 \pm$ & $0.85 \pm 0.05$ & $371.06 \pm$ \\
& 703.17 & 605.32 & 70.41 & & 20.51 \\
OVX + 30 $\mathrm{mg} / \mathrm{kg}$ & $380,427.53 \pm$ & $226,381.47 \pm$ & $8,031.39 \pm$ & $0.88 \pm 0.03$ & $379.14 \pm$ \\
& 663.14 & 737.92 & 77.34 & & 22.15 \\
OVX + 40 $\mathrm{mg} / \mathrm{kg}$ & $387,935.52 \pm$ & $238,461.59 \pm$ & $8,935.42 \pm$ & $0.91 \pm 0.04$ & $387.46 \pm$ \\
& 935.27 & 694.11 & 90.75 & & \\
\hline
\end{tabular}




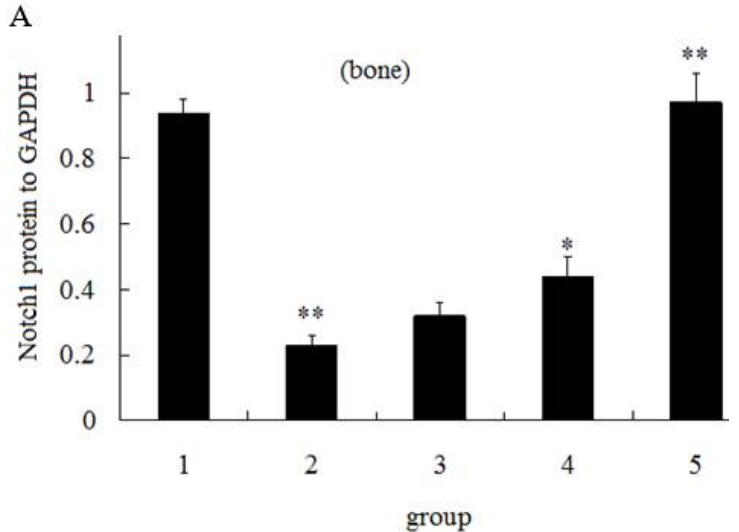

B
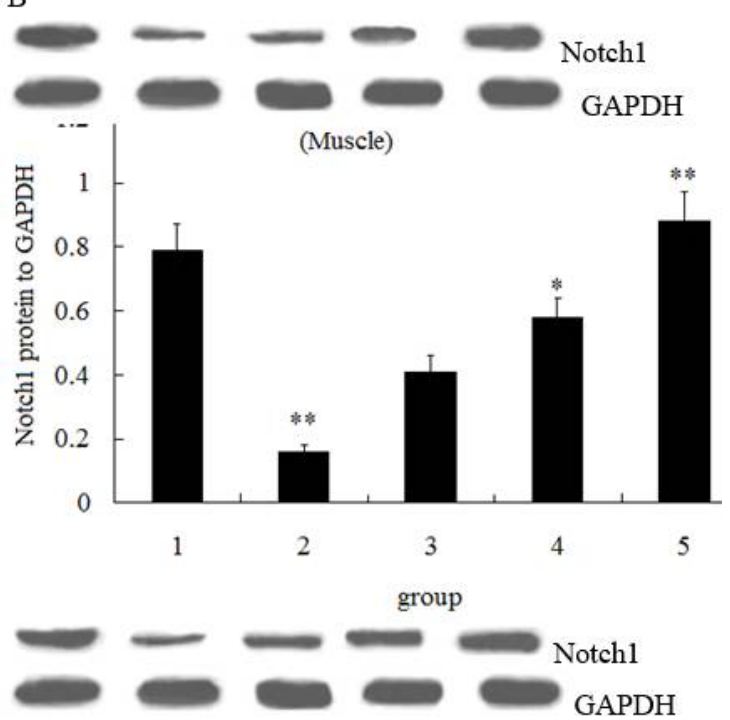

Figure 5: Soy isoflavone supplementation restores Notch1 protein expression in femur $(A)$ and muscle $(B)$ tissue. 1, intact rats; 2 , untreated OVX rats; $3-5$, OVX rats treated with 20,30 , or $40 \mathrm{mg} / \mathrm{kg}$ isoflavones, respectively; ${ }^{*} p<0.05,{ }^{* *} p<0.01$

tion is at the expense of osteoplastic replacement, resulting in reduced bone formation $[14,15]$.

Thus, we examined whether isoflavones, which can mimic some of the actions of oestrogen, can influence this process and suppress bone loss. It was observed that supplementation with dietary soy isoflavones inhibited OVX-induced osteoporosis in rats. The effect was observed in BMD and serum levels of ALP and BGP, which are indicators of bone formation and turnover. Whereas ALP catalyses osteoid formation and bone mineralization, BGP is a non-collagenous protein that regulates bone mineralization and suppresses abnormal hydroxyapatite crystallization and cartilage mineralization, thereby balancing bone remodelling processes [16-18]. Accordingly, we observed that OVX animals treated with soy isoflavones had increased concentrations of $\mathrm{Ca}, \mathrm{P}, \mathrm{Mg}, \mathrm{Mn}$, and $\mathrm{Zn}$ in bone, which are indicators of the mineral content and degree of mineralization in bone tissue [19]. Moreover, soy isoflavones dosedependently restored the transcription of osteoblast-related genes (Ctnnb1, Runx2, and Sp7) in OVX rats. Thus, the high-dose administration of soy isoflavones inhibited the OVX-induced bone loss, which was demonstrated by an increase in the maximum load capacity of lumbar vertebrae.

Notch1 is one of the four Notch proteins, which are transmembrane receptors that regulate highly conserved cell-fate decisions during embryonic development and throughout adulthood, including in the placenta during pregnancy [20]. Notch1 also regulates the differentiation and decidualization of stromal cells in the endometrium [20]. The expression of Notch1 dropped dramatically in OVX rats but was restored by supplementation with dietary isoflavones.

\section{CONCLUSION}

The results demonstrate that soy isoflavones inhibit bone loss and alleviate osteoporosis in rats, in part, via upregulation of Notch signalling. This suggests that soy isoflavones can potentially be applied to mitigate the effects of postmenopausal bone loss.

\section{DECLARATIONS}

\section{Acknowledgement}

This study was supported by the Foundation of Research on Technology and Quality Standards of Mixture Formula for Regulating Stomach and Releasing Excessive Turbid (no. ZRQN1509, 030029031 to Wei Jin).

\section{Conflict of Interest}

No conflict of interest associated with this work.

\section{Contribution of Authors}

The authors declare that this work was done by the authors named in this article and all liabilities pertaining to claims relating to the content of this article will be borne by them.

\section{REFERENCES}

1. Paschalis EP, Betts F, Di Carlo E, Mendelsohn R, Boskey AL. FTIR microspectroscopic analysis of human iliac crest biopsies from untreated osteoporotic bone. Calcif Tissue Int, 1997; 61: 487-492

2. Du Z, Steck R, Doan N, Woodruff M, Ivanovski S, Xiao Y. Estrogen deficiency associated bone loss in the maxilla: 
a methodology to quantify the changes in the maxillary intra-radicular alveolar bone in an ovariectomized rat osteoporosis model. Tissue Eng Part C Methods, 2015; 21 (5): 458-466

3. Holzmann K. Letter: estrogen deficiency and osteoporosis. Dtsch Med Wochenschr, 1974; 99: 13821383

4. Kalu DN. The ovariectomized rat model of postmenopausal bone loss. Bone Miner, 1991; 15: 175191

5. Baldi S, Becorpi A. Prevention, diagnosis and treatment of osteoporosis following menopause induced due to oncological disease Clinical Cases in Mineral and Bone Metabolism: Off. J. Italian Soc. Osteoporos. Miner Metab Skelet Dis, 2009; 6: 261-263

6. Clement A. Advanced in the treatment of the menopause and osteoporosis. Br J Obstet Gynaecol, 1994; 101: 170-174

7. Meema HE, Meema S. Prevention of postmenopausal osteoporosis by hormone treatment of the menopause. Can Med Assoc J, 1968; 99: 248-251

8. Anderson JJ, Anthony MS, Cline JM, Washburn SA, Garner SC. Health potential of soy isoflavones for menopausal women. Public Health Nutr, 1999; 2 (4): pp. 489-504

9. Kim J. Protective effects of Asian dietary items on cancers-Soy and ginseng. Asian Pac J Cancer Prev, 2008; 9 (4): 543-548

10. Office of Laboratory Animal Welfare/National Institutes of Health. 2002. Public Health Service policy on human care and use of laboratory animals. National Institute of Health, Bethesda, Maryland. Available from: http://grants.nih.gov/grants/olaw/references/phspol.htm.

11. Gonen $Y$, Balakier $H$, Powell W, Casper RF. Use of gonadotropin-releasing maturation for in vitro fertilization. J Clin Endocrinol Metab, 1990; 71: 918-922
12. Pastoureau P, Chomel A, Bonnet J. Specific evaluation of localized bone mass and bone loss in the rat using dual energy $X$-ray absorptiometry subregional analysis. Osteoporos Int, 1995; 5: 143-149

13. Raisz LG. Pathogenesis of osteoporosis: concepts, conflicts, and prospects. J Clin Invest, 2005; 115: 33183325

14. Wronski TJ, Dann LM, Scott KS, Crooke LR. Endocrine and pharmacological suppressors of bone turnover protect against osteopenia in ovariectomised rats. Endocrinology, 1989; 125: 810-816

15. Turner RT, Vandersteenhove JJ, Bell NH. The effect of ovariectomy and 17beta-estradiol on bone histomorphometry in growing rats. J Bone Miner Res, 1987; 2: 115-122

16. Yilmaz N, Bayram M, Erbåğci AB, Kilinçer MS. Diagnostic value of biochemical markers of bone turnover and postmenopausal osteoporosis. Clin Chem Lab Med, 1999; 37: 137-143

17. Verit FF, Geyikli I, Yazgan P, Celik A. Correlations of serum prolidase activity between bone turnover markers and mineral density in postmenopausal osteoporosis. Arch Gynecol Obstetr, 2006; 274: 133-137

18. Verit $H, M a M H$, Nian SS, $X u$ LL. Antiosteoporotic activity of icariin in ovariectomized rats. Phytomedicine, 2009; 16: 320-326

19. Carden A, Morris MD. Application of vibrational spectroscopy to the study of mineralized tissues (review). J Biomed Opt, 2000; 5: 259-268

20. Afshar Y, Jeong JW, Roqueiro D, DeMayo F, Lydon J, Radtke F, Radnor R, Miele L, Fazleabas A. Notch1 mediates uterine stromal differentiation and is critical for complete decidualization in the mouse. FASEB J., 2012; 26: 282-294. 